\title{
Zeolite Synthesized from Coal Fly Ash Produced by a Gasification Process for $\mathrm{Ni}^{2+}$ Removal from Water
}

\author{
Yixin Zhang ${ }^{1}$, Jixiang Dong ${ }^{2}$, Fanhui Guo ${ }^{2}$, Zhongye Shao ${ }^{2}$ and Jianjun Wu ${ }^{2, *}$ \\ 1 National Engineering Research Center of Coal Preparation and Purification, China University of Mining and \\ Technology, No.1 Daxue Road, Xuzhou 221116, China; yixinzhang@cumt.edu.cn \\ 2 School of Chemical Engineering and Technology, China University of Mining and Technology, No.1 Daxue \\ Road, Xuzhou 221116, China; Dongjixiang@cumt.edu.cn (J.D.); fanhuiGuo@cumt.edu.cn (F.G.); \\ zhongyeshao@cumt.edu.cn (Z.S.) \\ * Correspondence: wujj@cumt.edu.cn or jjuw@163.com; Tel.: +86-05-168-359-1115
}

Received: 24 January 2018; Accepted: 13 March 2018; Published: 14 March 2018

\begin{abstract}
There are increasing demands and great potential of coal gasification in China, but there is a lack of studies focused on the disposal and utilization of coal fly ash produced by the gasification process. In this study, a coal fly ash sample derived from a gasifier in Jincheng, China, was utilized as raw material for the synthesis of zeolite by alkali fusion followed by hydrothermal treatments. The effects of operation conditions on the cation exchange capacity (CEC) of synthesized zeolite were investigated. The synthesized zeolite with the highest CEC $(270.4 \mathrm{meq} / 100 \mathrm{~g})$, with abundant zeolite $\mathrm{X}$ and small amount of zeolite $\mathrm{A}$, was produced by $1.5 \mathrm{~h}$ alkali fusion under $550{ }^{\circ} \mathrm{C}$ with $\mathrm{NaOH} /$ coal fly ash ratio $1.2 \mathrm{~g} / \mathrm{g}$ followed by $15 \mathrm{~h}$ hydrothermal treatment under $90{ }^{\circ} \mathrm{C}$ with liquid/solid ratio $5 \mathrm{~mL} / \mathrm{g}$ and applied in $\mathrm{Ni}^{2+}$ removal from water. The removal rate and the adsorption capacity of $\mathrm{Ni}^{2+}$ from water by the synthesized zeolite were determined at the different $\mathrm{pH}$, contact time, adsorbent dose and initial $\mathrm{Ni}^{2+}$ concentration. The experimental data of adsorption were interpreted in terms of Freundlich and Langmuir equations. The adsorption of $\mathrm{Ni}^{2+}$ by the synthesized zeolite was found to fit sufficient using the Langmuir isotherm. More than $90 \%$ of $\mathrm{Ni}^{2+}$ in water could be removed by synthesized zeolite under the proper conditions. We show that the coal fly ash produced by the gasification process has great potential to be used as an alternative and cheap source in the production of adsorbents.
\end{abstract}

Keywords: coal fly ash; gasification; synthetic zeolite; nickel; adsorption

\section{Introduction}

Nickel is widely used in electroplating and metal finishing for improving the corrosion resistance as well as decorative characteristics [1]. A large number of $\mathrm{Ni}^{2+}$-containing wastewater is produced. Nickel may cause different types of diseases, such as lung cancer, kidney problems, gastrointestinal disorders, pulmonary fibrosis, skin dermatitis, rapid respiration, cyanosis, and extreme weakness if it is beyond the permitted concentration [2-5]. The treatment of wastewater containing heavy metals in a safe, effective and economic way is always challenging. Several methods have been developed to remove heavy metals from wastewater, such as precipitation, ion exchange, adsorption, membrane filtration and electrodialysis, but many of these methods need high capital costs when they are applied to large scale wastewater treatment. Adsorption is recognized to be a feasible method for the removal of heavy metals from wastewater because the adsorbent can be chosen from a wide variety of budget materials, such as synthetic zeolite from coal fly ash [6,7].

In China, more than $60 \%$ of primary energy is generated from coal. Coal fly ash is mainly generated from the combustion of pulverized coal in coal-fired power plants [8,9], which has consumed nearly $60 \%$ of coal in China in recent years. According to the National Development and Reform 
Commission (NDRC) of China, 540 million ton of coal fly ash was generated in 2015. The coal fly ash is recognized to be environmental pollutant if it cannot be disposed properly [9], but it is a budget absorbent to remove organic compounds, dyes and heavy metals from wastewater. Rao et al. [10] compared the sorption of $\mathrm{Cr}^{6+}$ and $\mathrm{Ni}^{2+}$ by coal fly ash and activated carbon under various conditions. To enhance the removal efficiencies and adsorption capacities, the modifications of coal fly ash are needed [11]. The cation exchange capacities of synthetic zeolite from coal fly ash were improved in comparison to the initial coal fly ashes [7]. The adsorption of heavy metals of the coal fly ashes could be enhanced by alkaline modification [6,7]. Molina et al. [12] reported a further improvement of the cation exchange capacities of synthetic zeolite from coal fly ash by introducing an alkali fusion stage prior to the conventional zeolite synthesis process. The synthesis and character of different type zeolites from coal fly ash under various operation conditions were studied by Kunecki et al. [13]. Wdowin et al. [14] and Querol et al. [15] reported the synthesis of zeolite from coal fly ash at sub-pilot and pilot scales. There are some publications about the regeneration of synthesized zeolite $[16,17]$, but only $60 \%$ adsorption capacity could be recovered and the chemical reagents were consumed during the regeneration. The zeolite from coal fly ash is low-cost adsorbent, and the reuse of zeolite is not economical. Usually, heavy metals could be stabilized and immobilized by zeolite to avoid the pollution of water $[18,19]$. All the aforementioned procedures are based on coal fly ash from combustion and very little research has been conducted on the field of coal fly ash from gasification.

Coal gasification is an important industrial process in which coal is converted to synthesize gas for use in power generation or as precursors for other transformations [20]. Coal gasification for advanced power generation has certain advantages over traditional pulverized-fuel combustion, such as high thermal efficiency and high efficiency in the removal of hazardous trace elements prior to combustion compared to post combustion systems [21]. To reduce the dependence on imported oil, the synthetic fuels industry from coal via gasification and subsequent liquefaction of fuel gases are continuously gaining ground in China. Due to the increasing demand and the great potential of coal gasification, it is meaningful to study the disposal and reuse of coal fly ash produced by the gasification process. The synthesis of zeolite to be used as a low-cost adsorbent is a feasible way for coal fly ash utilization, and the synthesis of zeolite from coal fly ash produced by combustion is widely reported $[6,7,22,23]$. There is, however, lack of information about the properties of zeolite synthesized from coal fly ash produced by gasification. In the gasification process, the coal fly ash is formatted under an inducing atmosphere, which results in the different mechanisms in mineral matter transfer and mineralogical properties of coal fly ash compared to combustion processes [24,25]. The mineralogical components in coal fly ash may affect the properties of the synthesized zeolite. This study aimed at investigating the potential of synthetic zeolite from gasification coal fly ash to be used as a low-cost adsorbent for the removal of heavy metals from water.

In this study, the characteristics of zeolite synthesized from coal fly ash produced by the gasification process by alkali fusion followed by hydrothermal treatments under varied conditions were analyzed. The adsorption behavior of synthetic zeolite of $\mathrm{Ni}^{2+}$ in water is discussed.

\section{Materials and Methods}

\subsection{Materials and Preparation}

The coal fly ash sample was obtained from a Shell gasifier in Jincheng, China. A S8 Tiger X-ray fluorescence (XRF) spectrometry (Bruker, Billerica, MA, USA) was employed to quantify major chemical compounds in the coal fly ash sample. The major chemical compounds of coal fly ash sample are $\mathrm{SiO}_{2}(39.84 \%), \mathrm{Al}_{2} \mathrm{O}_{3}(22.42 \%), \mathrm{CaO}(6.12 \%), \mathrm{Fe}_{2} \mathrm{O}_{3}(5.91 \%), \mathrm{K}_{2} \mathrm{O}(1.47 \%)$ and unburned carbon $(15.20 \%)$ (Table 1$)$. The unburnt carbon was removed by calcination at $815( \pm 10){ }^{\circ} \mathrm{C}$ for $5 \mathrm{~h}$. To remove the alkaline oxide $\left(\mathrm{CaO}, \mathrm{Fe}_{2} \mathrm{O}_{3}\right.$ and $\left.\mathrm{K}_{2} \mathrm{O}\right)$, the coal fly ash sample was mixed with excessive $\mathrm{HCl}$ (mass concentration $20 \%$ ) with stirring for $1 \mathrm{~h}$. The coal fly ash sample was filtered and washed with distilled 
water until no $\mathrm{Cl}^{-}$was detected by $\mathrm{AgNO}_{3}$, then dried for subsequent processes. The adsorption capacity of the coal fly ash for $\mathrm{Ni}^{2+}$ is $0.91 \mathrm{mg} / \mathrm{g}$.

Table 1. The major chemical compounds of coal fly ash from gasification (wt \%, dry basis).

\begin{tabular}{cccccccc}
\hline Compound & $\mathrm{SiO}_{2}$ & $\mathrm{Al}_{2} \mathbf{O}_{3}$ & $\mathrm{CaO}$ & $\mathrm{Fe}_{2} \mathbf{O}_{3}$ & $\mathbf{K}_{2} \mathbf{O}$ & Unburnt Carbon & Others \\
\hline Content $(\%)$ & 39.84 & 22.42 & 6.12 & 5.91 & 1.47 & 15.20 & 9.04 \\
\hline
\end{tabular}

\subsection{Zeolite Synthesis}

The zeolite was synthesized from the coal fly ash by alkali fusion followed by hydrothermal treatments [26]. The weighted $\mathrm{NaAlO}_{2}$ was added to the coal fly ash sample to modify the $\mathrm{Si} / \mathrm{Al}$ ratio in mole to $2: 1$. The mixture of $\mathrm{NaOH}$ and coal fly ash sample in a pre-determined ratio was milled and fused at desired temperatures ranging from 450 to $650{ }^{\circ} \mathrm{C}$ for 0.5 to $2 \mathrm{~h}$. The $\mathrm{NaOH} / \mathrm{coal}$ fly ash ratio (by weight) was varied from 1 to $1.5 \mathrm{~g} / \mathrm{g}$. The mixture was then cooled to room temperature. The distilled water was added to the mixture at desired ratio from 3 to $15 \mathrm{~mL} / \mathrm{g}$. The slurry thus obtained was stirred mechanically for $12 \mathrm{~h}$. It was then crystallized by hydrothermal process under static conditions at desired temperatures ranging from 70 to $100{ }^{\circ} \mathrm{C}$ for 8 to $24 \mathrm{~h}$. The resultant precipitate was repeatedly washed by distilled water and filtered until excess $\mathrm{NaOH}$ was completely removed. The synthesized zeolite was obtained after the drying of precipitate.

\subsection{Characterization of Samples}

The cation exchange capacity (CEC) of sample was determined by a modified ammonium acetate method [12]. The $5 \mathrm{~g}$ sample was mixed with $100 \mathrm{~mL}$ of $1 \mathrm{M}$ ammonium acetate solution under room temperature for $16 \mathrm{~h}$ with stirring at $150 \mathrm{r} / \mathrm{min}$. The solid was then filtered and rinsed with methanol to remove the ammonium acetate solution. The ammonia was liberated by distillation of the solid mixed with 100 distilled water containing $4 \mathrm{~g}$ magnesium oxide, then absorbed in $50 \mathrm{~mL}$ of boric acid solution (mass concentration $2 \%$ ). The resultant absorbed solution was directly titrated with $0.1 \mathrm{M}$ $\mathrm{HCl}$ solution. The CEC value of sample was calculated as following:

$$
\mathrm{CEC}=\frac{N \times\left(V-V_{0}\right)}{m} \times 100
$$

where, CEC is the cation exchange capacity value of sample, meq/100 g; $N$ is the mole concentration, $\mathrm{mol} / \mathrm{L} ; V$ and $V_{0}$ are the volumes of $\mathrm{HCl}$ consumed by absorbed solution and blank solution, respectively, $\mathrm{mL} ; \mathrm{m}$ is the weight of sample, $\mathrm{g}$. The tests for each sample were implemented 3 times. The errors were less than $\pm 5 \mathrm{meq} / 100 \mathrm{~g}$.

The mineralogical composition of the zeolitic materials was identified by X-ray diffraction (XRD) with D8 Advance X-ray diffractometer (Bruker). The morphological analysis of sample was performed by scanning electron microscope (SEM) with Quanta FEG 250 (FEI, Thermo Fisher Scientific, Waltham, MA, USA).

\subsection{Adsorption Experiments}

For each experiment, a calculated amount of adsorbent was added to $100 \mathrm{~mL}$ of synthetic aqueous solution containing $\mathrm{Ni}^{2+}$ in $200 \mathrm{~mL}$ shake flask. The adsorbent dose and the concentration of $\mathrm{Ni}^{2+}$ were ranging from 1 to $6 \mathrm{~g} / \mathrm{L}$ and from 10 to $100 \mathrm{mg} / \mathrm{L}$, respectively. The $\mathrm{pH}$ adjustment of solution was done by using 1.0 M HCL and 1.0 M NaOH. The shake flask was agitated at a speed of $100 \mathrm{rpm}$ in a mechanical shaker with water bath at $30{ }^{\circ} \mathrm{C}( \pm 0.5)$. At the end, the adsorbent particles were separated from the suspensions by filtration. The residual concentration of $\mathrm{Ni}^{2+}$ in the filtrate was determined by a UV-2500 spectrophotometer (Shimadzu, Kyoto, Japan). The adsorption capacity of adsorbent was calculated as following:

$$
q_{t}=\frac{\left(C_{0}-C_{t}\right) V \times 10^{-3}}{m}
$$


where, $q_{t}$ is the adsorption capacity of the adsorbent at time $t, \mathrm{mg} / \mathrm{g} ; C_{0}$ is the initial concentration of $\mathrm{Ni}^{2+}$ in aqueous solution, $\mathrm{mg} / \mathrm{L} ; C_{t}$ is the residual concentration of $\mathrm{Ni}^{2+}$ in aqueous solution at time $\mathrm{t}, \mathrm{mg} / \mathrm{L} ; V$ is the volume of aqueous solution sample, $\mathrm{mL} ; m$ is the mass of adsorbent, $\mathrm{g}$. The $\mathrm{Ni}^{2+}$ removal rate was calculated as following:

$$
\eta_{t}=\frac{C_{0}-C_{t}}{C_{0}} \times 100 \%
$$

where, $\eta_{t}$ is the $\mathrm{Ni}^{2+}$ removal rate at time $t, \%$. The tests for each sample were implemented 3 times. The errors were less than $\pm 3 \%$.

\section{Results and Discussion}

\subsection{Effect of Operation Conditions on the Cation Exchange Capacity (CEC) of Synthesized Zeolite}

\subsubsection{Effect of $\mathrm{NaOH} /$ Fly Ash Ratio}

The effects of $\mathrm{NaOH} /$ coal fly ash ratio on the CEC of synthesized zeolite from coal fly ash are shown in Figure 1. It can be seen that the CEC of synthesized zeolite from coal fly ash increased with the increase of $\mathrm{NaOH} / \mathrm{coal}$ fly ash ratio from 1.0 to $1.2 \mathrm{~g} / \mathrm{g}$, and then started to decrease. A similar result was reported by Molina et al. [12]. The presence of $\mathrm{NaOH}$ in the mixture reacted with quartz and mullite in coal fly ash during fusion and contributed to the formation of soluble silicate and aluminate salts (Equations (4) and (5)). A higher concentration of soluble silicate and aluminate salts and a higher yield of zeolitic materials in the subsequent process could be achieved. The enhancement of the formation of zeolitic materials resulted in the increase of the CEC of synthesized zeolite from coal fly ash. The presence of $\mathrm{Na}^{+}$which is known to stabilize the sub-building units of zeolite frameworks also exerted positive effects during the zeolitization process [26]. The presence of $\mathrm{NaOH}$ affects not only the degree of zeolitisation but also the type of zeolite obtained as a product. Molina et al. [12] reported that the maximum proportion of zeolite $\mathrm{X}$ was achieved at a $\mathrm{NaOH} / \mathrm{fly}$ ash ratio of 1.2. With the further increase of $\mathrm{NaOH} /$ fly ash ratio, the extra $\mathrm{NaOH}$ reacted with soluble silicate and aluminate salts which resulted in the formation of hydroxysodalite during both alkali fusion and hydrothermal treatment processes. Because of the larger pore size and specific surface area of zeolite $X$ than hydroxysodalite, products rich in zeolite $\mathrm{X}$ have a better performance in cation exchange capacity test $[11,13]$.

$$
\begin{gathered}
2 \mathrm{NaOH}+\mathrm{SiO}_{2} \stackrel{\text { fusion }}{\rightarrow} \mathrm{Na}_{2} \mathrm{SiO}_{3}+\mathrm{H}_{2} \mathrm{O} \\
10 \mathrm{NaOH}+3 \mathrm{Al}_{2} \mathrm{O}_{3} \cdot 2 \mathrm{SiO}_{2} \stackrel{\text { fusion }}{\rightarrow} 2 \mathrm{Na}_{2} \mathrm{SiO}_{3}+6 \mathrm{NaAlO}_{2}+5 \mathrm{H}_{2} \mathrm{O}
\end{gathered}
$$

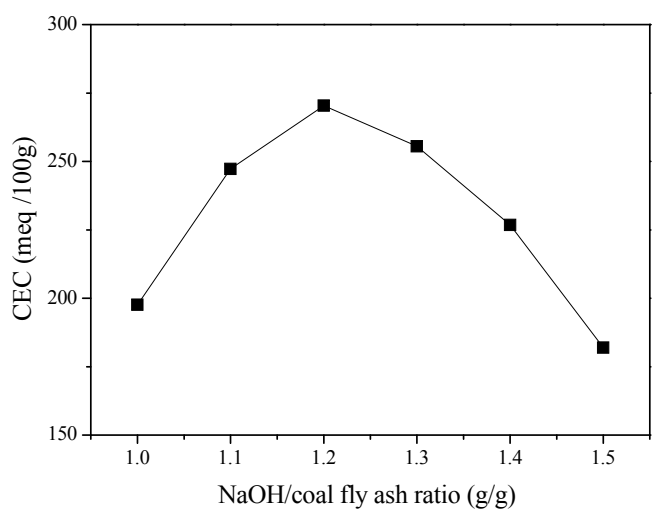

Figure 1. Effect of $\mathrm{NaOH} /$ coal fly ash ratio on the cation exchange capacity (CEC) of synthesized zeolite (liquid/solid ratio $5 \mathrm{~mL} / \mathrm{g}, 1.5 \mathrm{~h}$ alkali fusion under $550{ }^{\circ} \mathrm{C}, 15 \mathrm{~h}$ hydrothermal treatments under $\left.90^{\circ} \mathrm{C}\right)$. 


\subsubsection{Effect of Liquid/Solid Ratio}

As shown in Figure 2, the maximum value of CEC corresponds to a liquid/solid ratio of $5 \mathrm{~mL} / \mathrm{g}$. Rujiwatra et al. [27] reported that the high water content in the reaction mixtures with solid/liquid ratio always led to the formation of unidentified phase, whereas the lower water content resulted in a higher selective synthesis of zeolite. The lower liquid/solid ratio means a higher probability to enhance the yield of selective products (such as zeolite X) [28]. The influence of other factors was also enhanced when the amount of water in the reaction mixtures was kept low [27]. Further decrease of liquid/solid ratio below $5 \mathrm{~mL} / \mathrm{g}$ also has negative effects on the synthesis of zeolite. The yield of zeolitic materials was restrained with low liquid/solid ratio, because the soluble silicate and aluminate salts could not be completely dissolved. The low liquid/solid ratio also resulted in the high $\mathrm{NaOH}$ concentration in slurry which enhanced the formation of hydrosodalite with low CEC [29]. Both the low yield of zeolitic materials and high proportion of hydrosodalite in products resulted in the decrease of CEC value.

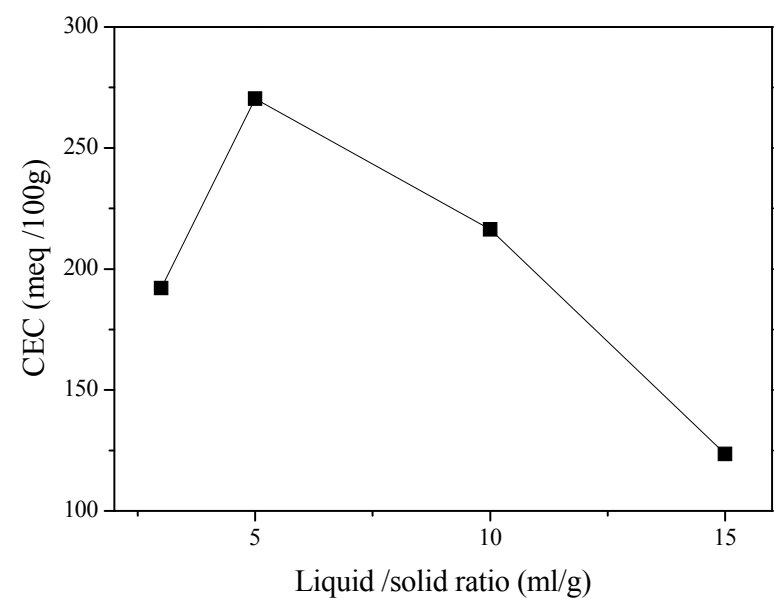

Figure 2. Effect of liquid/solid ratio on the CEC of synthesized zeolite $(\mathrm{NaOH} / \mathrm{coal}$ fly ash ratio $1.2 \mathrm{~g} / \mathrm{g}, 1.5 \mathrm{~h}$ alkali fusion under $550{ }^{\circ} \mathrm{C}, 15 \mathrm{~h}$ hydrothermal treatments under $90^{\circ} \mathrm{C}$ ).

\subsubsection{Effect of Alkali Fusion Conditions}

The effects of alkali fusion conditions on the CEC of synthesized d zeolite are given in Figure 3. The CEC of synthesized zeolite first increased with the increase of fusion temperature, attained a maximum at $550{ }^{\circ} \mathrm{C}$ and then decreased with the further increase of fusion temperature (Figure 3a). It was reported that the increase of the yield of zeolite was observed from temperatures above the melting point of $\mathrm{NaOH}\left(318^{\circ} \mathrm{C}\right)$ to a maximum crystallinity at $550^{\circ} \mathrm{C}[26,28]$. With the further increase of fusion temperature, the crystallinity of the synthesized zeolite was found to decrease due to the formation of non-crystalline sintered glass [28,30]. The crystallinity was supposed to be the most important factor that affects the CEC of synthesized zeolite under variation of fusion temperature. The CEC of synthesized zeolite increased quickly with fusion time until $1.5 \mathrm{~h}$; after that, no significant increase of the CEC of synthesized zeolite was observed (Figure 3b). It means that the reactions between $\mathrm{NaOH}$ and the coal fly ash were almost completed during $1.5 \mathrm{~h}$ alkali fusion process under $550{ }^{\circ} \mathrm{C}$. The further increase of fusion time could not help the activation of coal fly ash, but increased the energy consumption. 


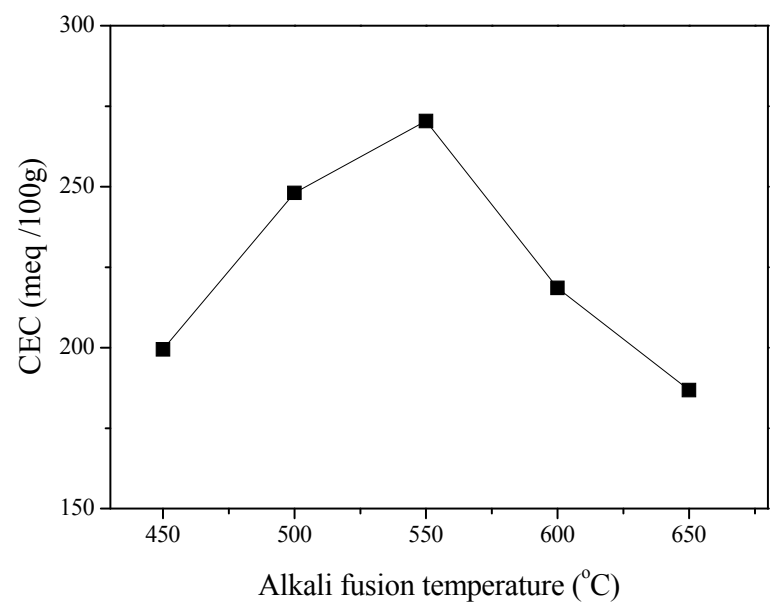

(a)

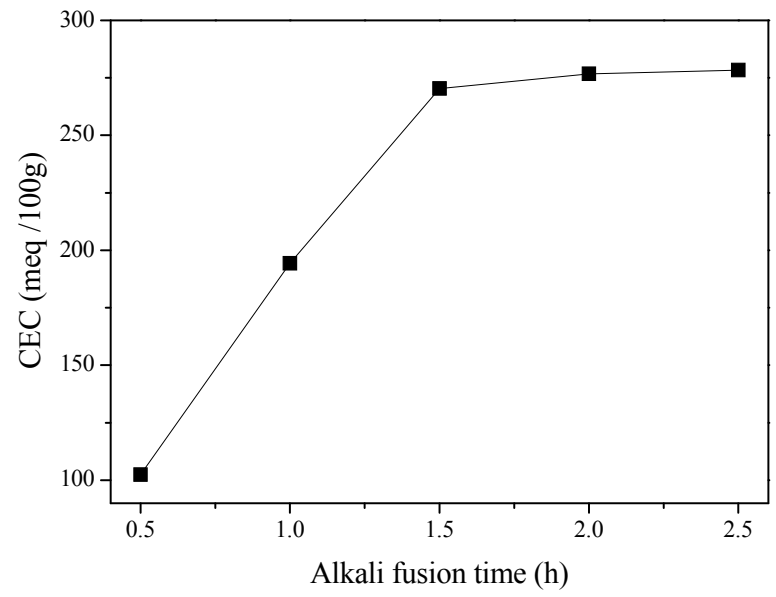

(b)

Figure 3. Effect of alkali fusion conditions on the CEC of synthesized zeolite ( $\mathrm{NaOH} /$ coal fly ash ratio $1.2 \mathrm{~g} / \mathrm{g}$, liquid/solid ratio $5 \mathrm{~mL} / \mathrm{g}$, $15 \mathrm{~h}$ hydrothermal treatments under $90^{\circ} \mathrm{C}$ ). (a) Alkali fusion temperature; (b) Alkali fusion time.

\subsubsection{Effect of Hydrothermal Treatment Conditions}

The variation of the CEC of synthesized zeolite as a function of hydrothermal treatment conditions is demonstrated in Figure 4. The optimal hydrothermal treatment temperatures were $90-100{ }^{\circ} \mathrm{C}$ (Figure 4a). If the hydrothermal treatment temperature is reduced, the yield of zeolitic materials will be reduced under a certain time due to the low reaction rate resulting in the reduction of CEC. Under hydrothermal treatment temperature above $120^{\circ} \mathrm{C}$, many of the high-CEC zeolites (such as zeolites X) cannot be effectively synthesized [11]. From Figure $4 b$, it is clear that the CEC of the synthesized zeolite increased gradually with the increase of hydrothermal treatment time up to $15 \mathrm{~h}$ and then decreased. It is reported that there is an incubation period of $3 \mathrm{~h}$ during which the nucleation of zeolites takes place following by progressively increasing in crystallinity up to a certain hydrothermal treatment time [26]. The increase of crystallinity dominated the increase of CEC of the synthesized zeolite with the increase of hydrothermal treatment time until $15 \mathrm{~h}$. After that, the further increase of hydrothermal treatment time resulted in the transformation of zeolite $\mathrm{X}$ to the more stable phillipsite phase with low CEC. 


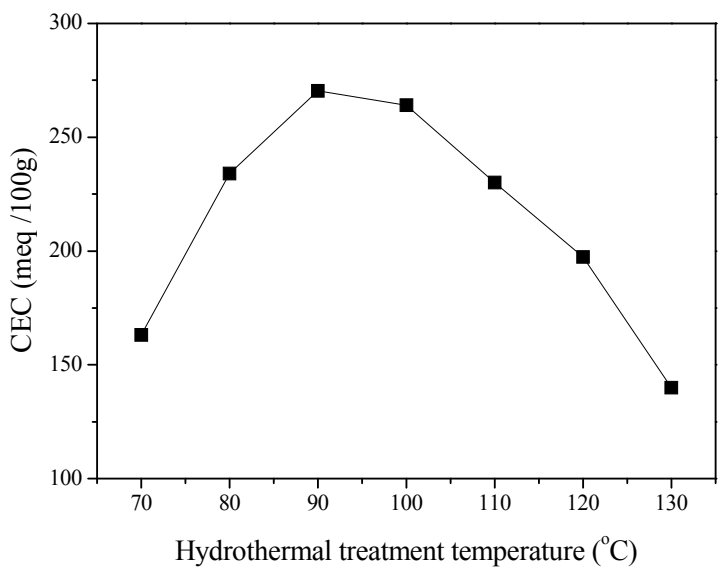

(a)

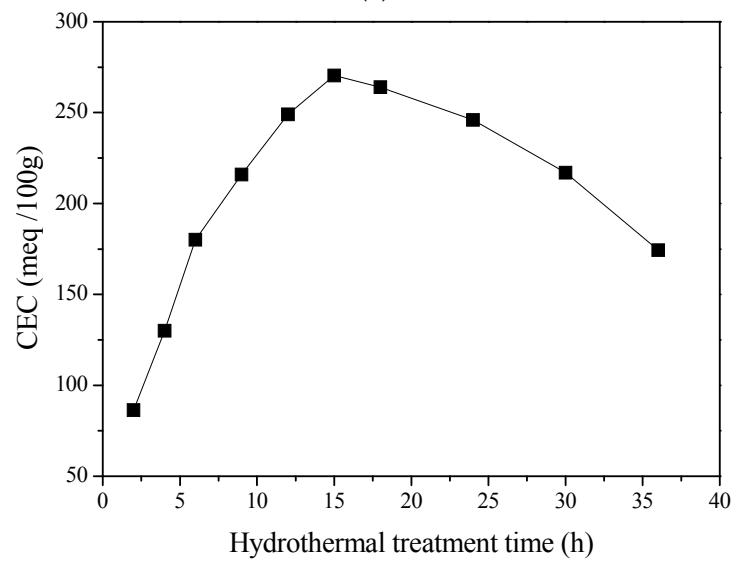

(b)

Figure 4. Effect of hydrothermal treatment conditions on the CEC of synthesized zeolite $(\mathrm{NaOH} / \mathrm{coal}$ fly ash ratio $1.2 \mathrm{~g} / \mathrm{g}$, liquid/solid ratio $5 \mathrm{~mL} / \mathrm{g}, 1.5 \mathrm{~h}$ alkali fusion under $550{ }^{\circ} \mathrm{C}$ ). (a) Hydrothermal treatment temperature; (b) Hydrothermal treatment time.

\subsubsection{Mineralogical and Morphological Analysis}

According to the zeolite synthetis experiments, the $\mathrm{NaOH}$ /coal fly ash ratio 1.2, liquid/solid ratio 5 , fusion temperature $550{ }^{\circ} \mathrm{C}$, fusion time $1.5 \mathrm{~h}$, hydrothermal treatment temperature $90{ }^{\circ} \mathrm{C}$ and hydrothermal treatment time of $15 \mathrm{~h}$ produced the highest CEC products and were selected as optimal conditions. The identification of mineralogical phases in and SEM results of the coal fly ash and zeolite synthesized under the optimal conditions are illustrated in Table 2 and Figure 5, respectively. The absences of calcite, illite, magnetire and hematite in the synthesized zeolite were due to the acid treatment of coal fly ash before the synthesis process. The presence of zeolite $\mathrm{X}$ and zeolite $\mathrm{A}$ indicated the formation of zeolite products from coal fly ash, which was also confirmed by SEM results. The spherical particles reflecting the shape of the coal fly ash particle which were observed in Figure 5a disappeared in the SEM of the synthesized zeolite (Figure $5 b$ ). The spherical particles were converted into some distorted octahedral crystals which were determined as the crystal structure of zeolite [26]. The absence of the spherical particles in synthesized zeolite indicates the high conversion of coal fly ash to zeolite by alkali fusion and hydrothermal treatment under optimal conditions. The crystal structures in synthesized zeolite were identified in Figure 5c. There were abundant distributions of octahedral crystals and small amounts of cubic crystals, which correspond to zeolite $\mathrm{X}$ and zeolite A, respectively. The zeolite synthesized from coal fly ash produced by a gasification process under the optimal conditions was used in the adsorption experiments. 
Table 2. Mineralogical phases identified in the coal fly ash and synthesized zeolite. (Y: presence of mineral phase, $\mathrm{N}$ : absence of mineral phase).

\begin{tabular}{ccc}
\hline Mineral & Coal Fly Ash & Synthesized Zeolite \\
\hline Quartz & Y & Y \\
Calcite & Y & Y \\
Mullite & Y & N \\
Illite & Y & N \\
Magnetite & Y & N \\
Hematite & Y & Y \\
Zeolite X & N & Y \\
Zeolite A & N &
\end{tabular}

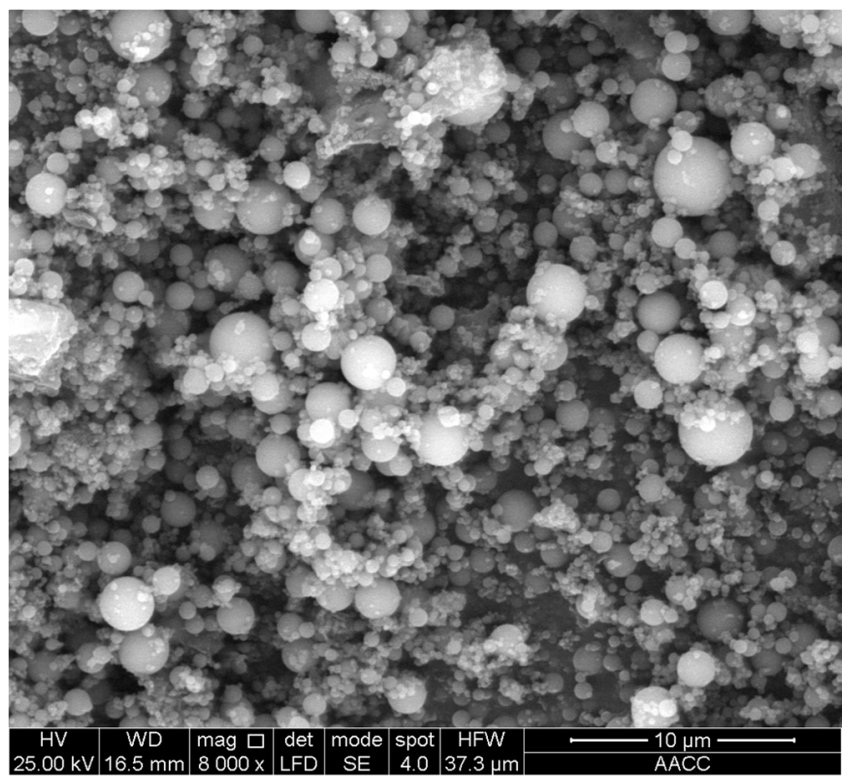

(a)

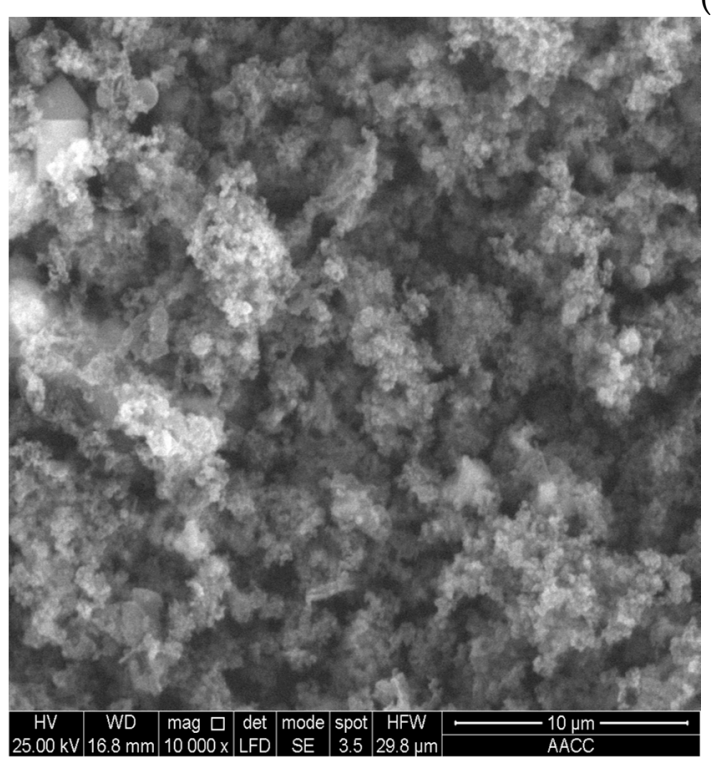

(b)

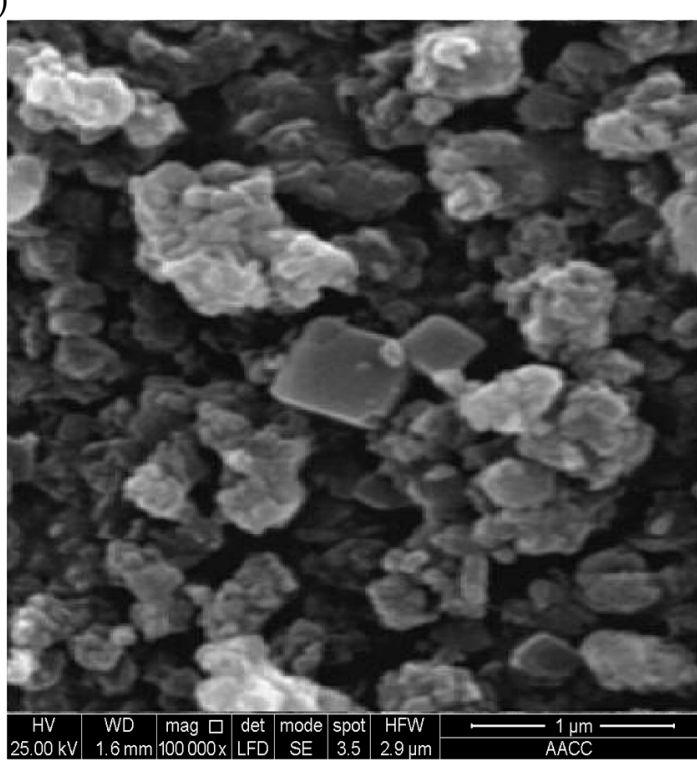

(c)

Figure 5. Scanning electron microscope (SEM) of coal fly ash and synthesized zeolite (a) coal fly ash; (b) synthesized zeolite; (c) crystal structures in synthesized zeolite. 


\subsection{Adsorption of $\mathrm{Ni}^{2+}$ by Synthesized Zeolite}

\subsubsection{Effect of $\mathrm{pH}$ on Adsorption}

As shown in Figure 6, the removal of $\mathrm{Ni}^{2+}$ from the aqueous solution was strongly affected by the $\mathrm{pH}$ of the solution. At $\mathrm{pH} 2$, the minimum removal rates and the adsorption capacity of $\mathrm{Ni}^{2+}$ were observed. With the increase of $\mathrm{pH}$ from 2 to 5, the removal rate and the adsorption capacity of $\mathrm{Ni}^{2+}$ increased quickly from $19 \%$ to $91 \%$ and from $1.52 \mathrm{mg} / \mathrm{g}$ to $7.28 \mathrm{mg} / \mathrm{g}$, respectively. At low $\mathrm{pH}$, the presence of higher concentrations of $\mathrm{H}^{+}$competed with $\mathrm{Ni}^{2+}$ in the system and caused partial releasing of the $\mathrm{Ni}^{2+}$ [31]. On the other hand, the solubility and ionization of nickel salt were strongly enhanced in low $\mathrm{pH}$ solution [32]. It could be deduced that at lower $\mathrm{pH}$, most of the activated sites on the surface of the synthesized zeolite were occupied by $\mathrm{H}^{+}$, inhibiting the adsorption of $\mathrm{Ni}^{2+}$. With the increase of $\mathrm{pH}$, the concentration of $\mathrm{H}^{+}$decreased, causing more and more activated sites on the surface of the synthesized zeolite to be available for $\mathrm{Ni}^{2+}$ adsorption. At the same time, the $\mathrm{Ni}^{2+}$ became less stable in the solution with increased $\mathrm{pH}$ which also enhanced the adsorption of $\mathrm{Ni}^{2+}$ [32]. With further increase of $\mathrm{pH}$ above 5 , the slight increase of removal of $\mathrm{Ni}^{2+}$ may be due to the formation of precipitation $[33,34]$. To avoid precipitation, $\mathrm{pH} 5$ was chosen as the optimum $\mathrm{pH}$ in this study.

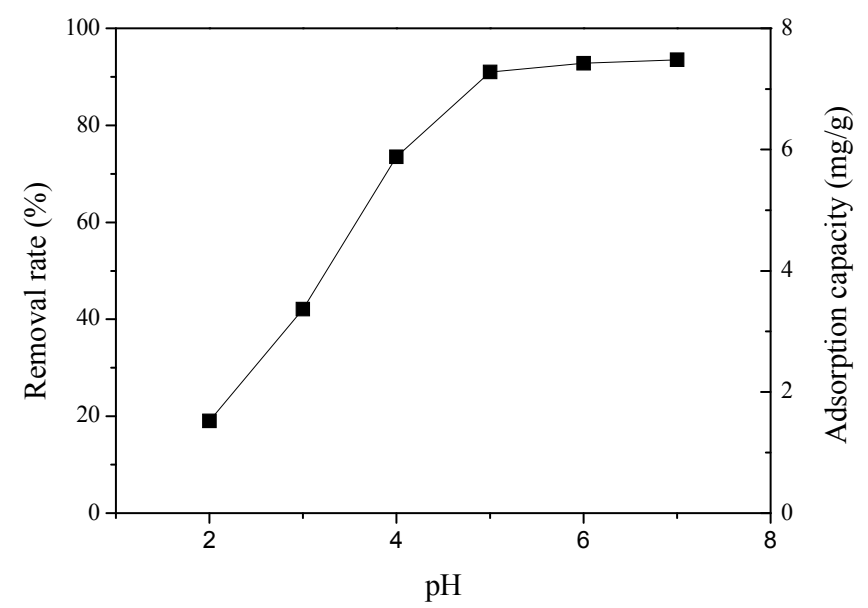

Figure 6. Effect of $\mathrm{pH}$ on the adsorption of $\mathrm{Ni}^{2+}$ by synthesized zeolite (contact time $30 \mathrm{~min}$, adsorbent dose $2.5 \mathrm{~g} / \mathrm{L}$, initial $\mathrm{Ni}^{2+}$ concentration $20 \mathrm{mg} / \mathrm{L}$ ).

\subsubsection{Effect of Contact Time on Adsorption}

The removal and the adsorption capacity of $\mathrm{Ni}^{2+}$ as a function of contact time were demonstrated in Figure 7. There was a rapid increase of the removal rate and adsorption capacity of $\mathrm{Ni}^{2+}$ in the first $5 \mathrm{~min}$ followed by a progressively slow increase with the increase of contact time. The adsorption of $\mathrm{Ni}^{2+}$ approached equilibrium with $30 \mathrm{~min}$; after that, further increase of contact time only resulted in slight increase of the removal rate and adsorption capacity of $\mathrm{Ni}^{2+}$. A similar trend was reported by Rao at al. [10] and Onundi et al. [32]. The high concentration gradient of $\mathrm{Ni}^{2+}$ between the solution and the surface of synthesized zeolite with abundantly exchangeable sites is deduced to be the reason of the rapid adsorption at the initial stage [32]. With the progress of adsorption, the concentration gradient of $\mathrm{Ni}^{2+}$ between the solution and the surface of synthesized zeolite gradually decreased until equilibrium adsorption was reached and the activated sites on the surface of the synthesized zeolite were gradually occupied. These limited the transfer of $\mathrm{Ni}^{2+}$ from the solution to the surface of the synthesized zeolite and caused progressively slow adsorption with the increase of contact time. 


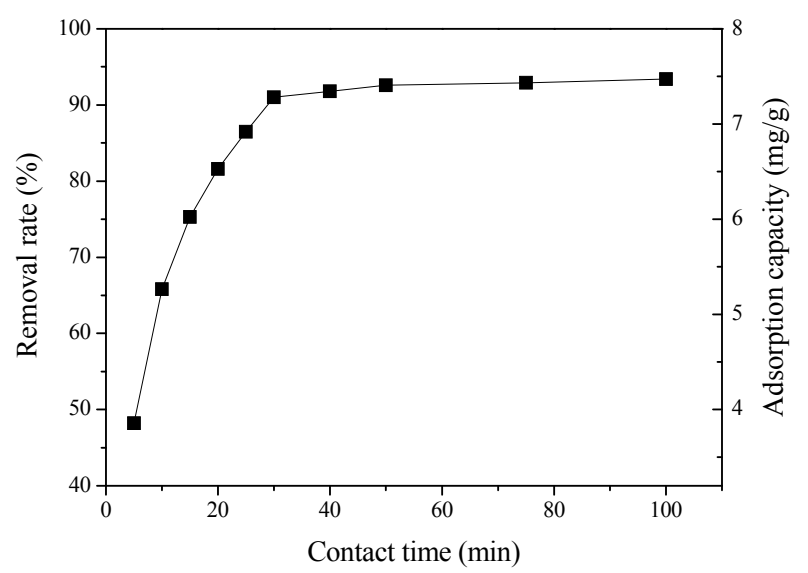

Figure 7. Effect of contact time on the adsorption of $\mathrm{Ni}^{2+}$ by synthesized zeolite $(\mathrm{pH} 5$, adsorbent dose $2.5 \mathrm{~g} / \mathrm{L}$, initial $\mathrm{Ni}^{2+}$ concentration $\left.20 \mathrm{mg} / \mathrm{L}\right)$.

\subsubsection{Effect of Adsorbent Dose on Adsorption}

The effect of adsorbent dose on the adsorption of $\mathrm{Ni}^{2+}$ is shown in Figure 8. It is seen that the removal rate of $\mathrm{Ni}^{2+}$ almost linearly increased with the increase of adsorbent dose from $1 \mathrm{~g} / \mathrm{L}$ to $2.5 \mathrm{~g} / \mathrm{L}$, while no obvious change was observed in the adsorption capacity of $\mathrm{Ni}^{2+}$. With the increase of adsorbent dose, the great increase of exchangeable sites on the surface of adsorbent resulted in the rapid increase of the removal of $\mathrm{Ni}^{2+}$ [34]. Due to the abundance of $\mathrm{Ni}^{2+}$ in solution, the exchangeable sites on the surface of adsorbent were sufficiently used, which kept the adsorption capacity at a relatively stable value. The further increase of adsorbent dose beyond $2.5 \mathrm{~g} / \mathrm{L}$ only resulted in a relatively slight enhancement of the removal of $\mathrm{Ni}^{2+}$, but a rapid decline in the adsorption capacity. The reduction in the adsorption capacity may be due to the overlapping of the exchangeable sites caused by the overcrowding of adsorbent particles [32].

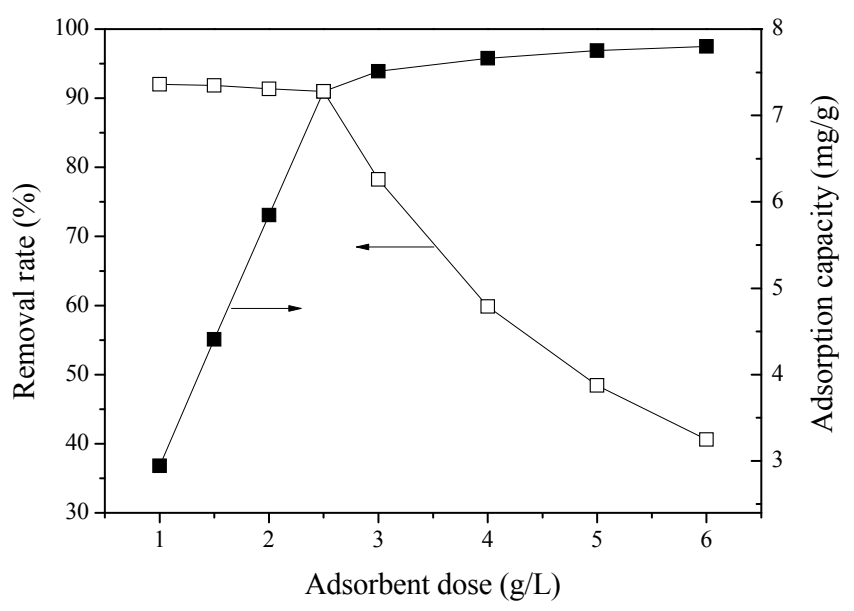

Figure 8. Effect of adsorbent dose on the adsorption of $\mathrm{Ni}^{2+}$ by synthesized zeolite ( $\mathrm{pH} 5$, contact time $30 \mathrm{~min}$, initial $\mathrm{Ni}^{2+}$ concentration $20 \mathrm{mg} / \mathrm{L}$ ).

\subsubsection{Effect of Initial $\mathrm{Ni}^{2+}$ Concentration on Adsorption}

The effect of initial $\mathrm{Ni}^{2+}$ concentration on the adsorption by synthesized zeolite was investigated by varying the initial concentration between 10 and $100 \mathrm{mg} / \mathrm{L}$. As shown in Figure 9, the removal rate and the adsorption capacity were $95 \%$ and $3.8 \mathrm{mg} / \mathrm{g}$ at the initial $\mathrm{Ni}^{2+}$ concentration $10 \mathrm{mg} / \mathrm{L}$. With the increase of initial $\mathrm{Ni}^{2+}$ concentration to $100 \mathrm{mg} / \mathrm{L}$, the removal rate dropped to $37.5 \%$ while the adsorption capacity increased to $15.0 \mathrm{mg} / \mathrm{L}$, approaching the maximum value. 


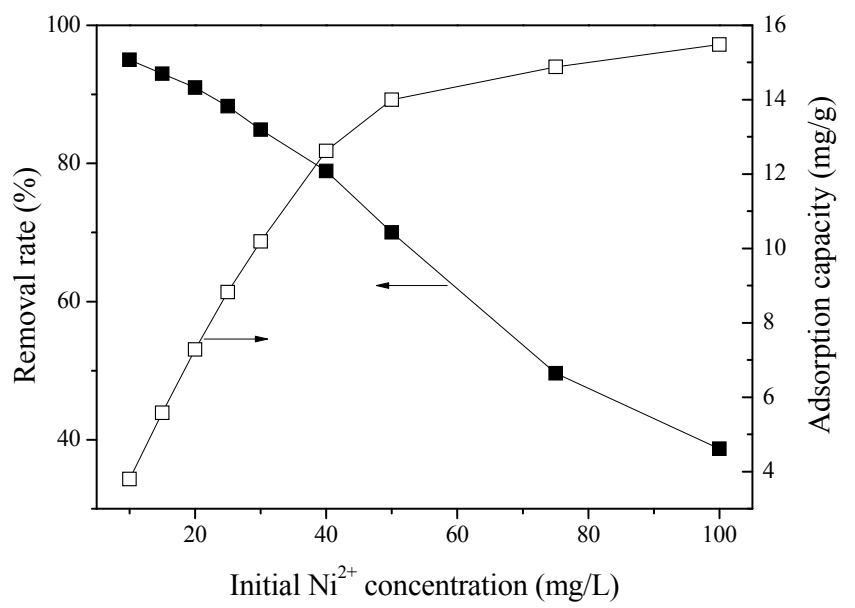

Figure 9. Effect of initial $\mathrm{Ni}^{2+}$ concentration on the adsorption of $\mathrm{Ni}^{2+}$ by synthesized zeolite ( $\mathrm{pH} 5$, contact time $30 \mathrm{~min}$, adsorbent dose $2.5 \mathrm{~g} / \mathrm{L}$ ).

\subsubsection{Adsorption Isotherm and Kinetics}

The Freundlich and Langmuir models are the most frequently used models to describe the experimental data of adsorption isotherms [3,10,32-35].

Freundlich isotherm is shown as:

$$
\log q_{e}=\log K_{f}+\frac{1}{n} \log C_{e}
$$

where $q_{e}$ is amount of solute adsorbed per unit weight of adsorbents, $\mathrm{mg} / \mathrm{g} ; C_{e}$ is the equilibrium concentration of the solute, $\mathrm{mg} / \mathrm{L} ; K_{f}$ and $n$ are the Freundlich constants which affected by the adsorption process, such as adsorption capacity and intensity of adsorption, respectively.

Langmuir isotherm is shown as:

$$
\frac{C_{e}}{q_{e}}=\frac{C_{e}}{q_{\max }}+\frac{1}{q_{\max } b}
$$

where $q_{\max }$ is the maximum adsorption capacity, $\mathrm{mg} / \mathrm{g} ; b$ is the Langmuir constants related to the energy of adsorption.

The Freundlich and Langmuir isotherm plots for the adsorption of $\mathrm{Ni}^{2+}$ are shown in Figure 10; the constants and correlation coefficients $r^{2}$ are listed in Table 3. The $r^{2}$ of Freundlich and Langmuir isotherm plots are 0.88 and 0.999 , respectively. The result indicates that the Langmuir model has perfect application for $\mathrm{Ni}^{2+}$ adsorption by zeolite synthesized by alkali fusion followed by hydrothermal treatments from coal fly ash produced by gasification. The maximum adsorption capacity for $\mathrm{Ni}^{2+}$ by synthesized zeolite was calculated as $15.936 \mathrm{mg} / \mathrm{g}$. There is a significant improvement in the adsorption capacity of gasification coal fly ash by synthesis of zeolite. The adsorption capacity of the synthesized zeolite from combustion coal fly ash for $\mathrm{Ni}^{2+}$ is varied in a wide range, from $8.69 \mathrm{mg} / \mathrm{g}$ to $59.89 \mathrm{mg} / \mathrm{g}[22,23,36]$. This may be due to the differences in the mineralogical properties between the coal fly ash from gasification and combustion and the methods for synthesis. Compared with the zeolite synthesized from combustion coal fly ash, the adsorption capacity of the synthesized zeolite in this study is acceptable, but there is still great potential in the further improvement of the adsorption capacity of zeolite synthesized from gasification coal fly ash. 


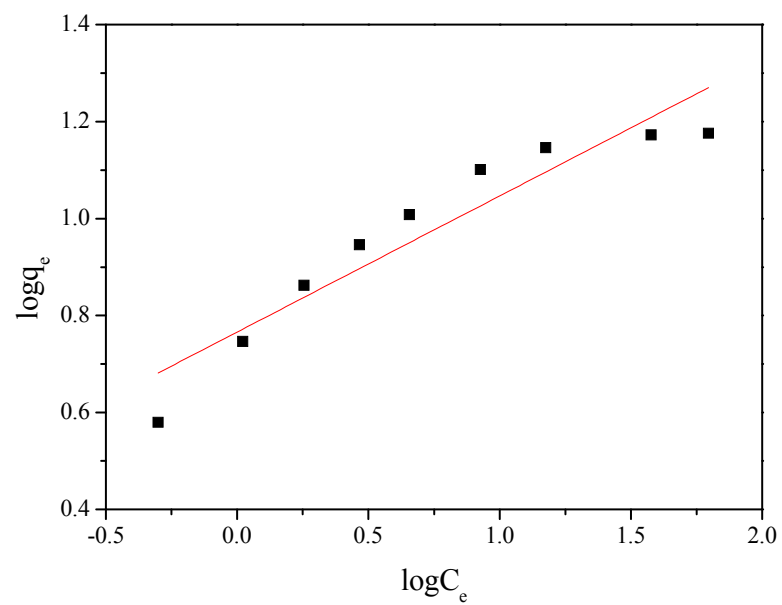

(a)

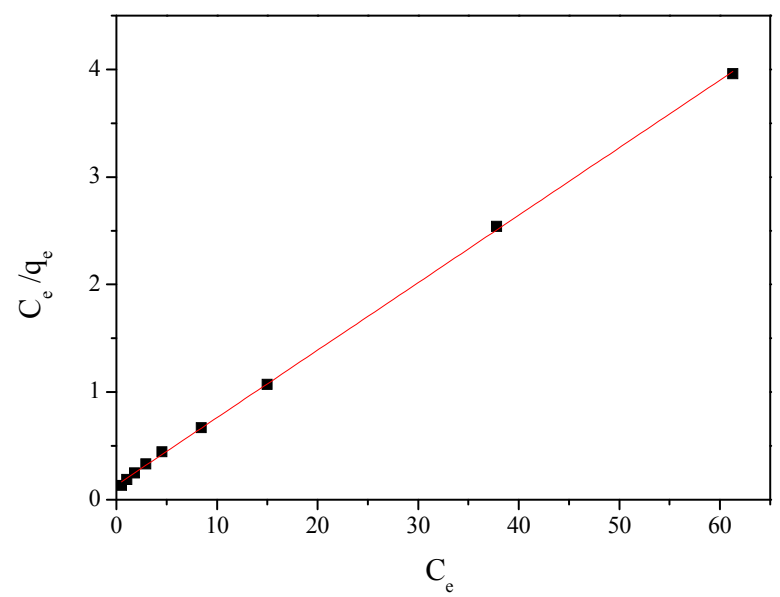

(b)

Figure 10. Freundlich and Langmuir isotherm plots for the adsorption of $\mathrm{Ni}^{2+}$ (a) Freundlich; (b) Langmuir.

Table 3. The constants and correlation coefficients of Freundlich and Langmuir isotherm plots for the adsorption of $\mathrm{Ni}^{2+}$.

\begin{tabular}{cccccc}
\hline \multicolumn{3}{c}{ Freundlich Constants } & \multicolumn{3}{c}{ Langmuir Constants } \\
\hline$K_{f}$ & $n$ & $r^{2}$ & $b$ & $q_{\max }(\mathrm{mg} / \mathrm{g})$ & $r^{2}$ \\
5.833 & 3.562 & 0.883 & 0.465 & 15.936 & 0.999 \\
\hline
\end{tabular}

\section{Conclusions}

In this study, the synthesis of zeolite from coal fly ash produced by a gasification process was carried out by alkali fusion followed by hydrothermal treatments. The quartz and mullite in coal fly ash reacted with $\mathrm{NaOH}$ and formatted soluble silicate and aluminate salts during alkali fusion which converted to zeolite in hydrothermal treatments. The effects of operation conditions on the CEC of the synthesized zeolite were systematically investigated. The synthesized zeolite with the highest CEC was produced under the following operation conditions: $\mathrm{NaOH} /$ coal fly ash ratio 1.2, liquid/solid ratio 5 , fusion temperature $550{ }^{\circ} \mathrm{C}$, fusion time $1.5 \mathrm{~h}$, hydrothermal treatment temperature $90{ }^{\circ} \mathrm{C}$ and hydrothermal treatment time $15 \mathrm{~h}$. There were abundant amounts zeolite $\mathrm{X}$ and small amounts of zeolite A in the synthesized zeolite produced under optimal condition.

The synthesized zeolite with the highest CEC was used in the experiments of $\mathrm{Ni}^{2+}$ removal from water. The effects of $\mathrm{pH}$, contact time, adsorbent dose and initial $\mathrm{Ni}^{2+}$ concentration on the 
adsorption of $\mathrm{Ni}^{2+}$ were tested. The adsorption of $\mathrm{Ni}^{2+}$ by synthesized zeolite could be well described by Langmuir isotherm. More than $90 \%$ of $\mathrm{Ni}^{2+}$ could be removed by the synthesized zeolite in proper conditions. We have shown that the coal fly ash produced by gasification has great potential to be used as an alternative and cheap source in the production of adsorbents by alkali fusion followed by hydrothermal treatments.

Acknowledgments: This work was jointly supported by the China Postdoctoral Science Foundation (No. 2016M601919), the National Key R\&D Program of China (No. 2016YFB0600401), the National Natural Science Foundation of China (No. 51704292) and the Fundamental Research Funds for the Central Universities (No. 2017QNA25 and No. CPEUKF1704).

Author Contributions: Yixin Zhang and Jianjun Wu conceived and designed the experiments; Jixiang Dong and Zhongye Shao performed the experiments; Jixiang Dong and Fanhui Guo analyzed the data; Yixin Zhang wrote the paper.

Conflicts of Interest: The authors declare no conflict of interest.

\section{References}

1. Benvenuti, T.; Krapf, R.S.; Rodrigues, M.A.S.; Bernardes, A.M.; Zoppas-Ferreira, J. Recovery of nickel and water from nickel electroplating wastewater by electrodialysis. Sep. Purif. Technol. 2014, 129, $106-112$. [CrossRef]

2. Borba, C.E.; Guirardello, R.; Silva, E.A.; Veit, M.T.; Tavares, C.R.G. Removal of nickel(II) ions from aqueous solution by biosorption in a fixed bed column: Experimental and theoretical breakthrough curves. Biochem. Eng. J. 2006, 30, 184-191. [CrossRef]

3. Boujelben, N.; Bouzid, J.; Elouear, Z. Adsorption of nickel and copper onto natural iron oxide-coated sand from aqueous solutions: study in single and binary systems. J. Hazard. Mater. 2009, 163, 376-382. [CrossRef] [PubMed]

4. Argun, M.E. Use of clinoptilolite for the removal of nickel ions from water: kinetics and thermodynamics. J. Hazard. Mater. 2008, 150, 587-595. [CrossRef] [PubMed]

5. Peng, C.; Jin, R.; Li, G.; Li, F.; Gu, Q. Recovery of nickel and water from wastewater with electrochemical combination process. Sep. Purif. Technol. 2014, 136, 42-49. [CrossRef]

6. Visa, M.; Chelaru, A.-M. Hydrothermally modified fly ash for heavy metals and dyes removal in advanced wastewater treatment. Appl. Surf. Sci. 2014, 303, 14-22. [CrossRef]

7. Koukouzas, N.; Vasilatos, C.; Itskos, G.; Mitsis, I.; Moutsatsou, A. Removal of heavy metals from wastewater using CFB-coal fly ash zeolitic materials. J. Hazard. Mater. 2010, 173, 581-588. [CrossRef] [PubMed]

8. Yao, Z.T.; Ji, X.S.; Sarker, P.K.; Tang, J.H.; Ge, L.Q.; Xia, M.S.; Xi, Y.Q. A comprehensive review on the applications of coal fly ash. Earth-Sci. Rev. 2015, 141, 105-121. [CrossRef]

9. Blissett, R.S.; Rowson, N.A. A review of the multi-component utilisation of coal fly ash. Fuel 2012, 97, 1-23. [CrossRef]

10. Raoa, M.; Parwatea, A.V.; Bholeb, A.G. Removal of $\mathrm{Cr}^{6+}$ and $\mathrm{Ni}^{2+}$ from aqueous solution using bagasse and fly ash. Waste Manag. 2002, 22, 821-830. [CrossRef]

11. Ahmaruzzaman, M. A review on the utilization of fly ash. Prog. Energy Combust. Sci. 2010, 36, 327-363. [CrossRef]

12. Molina, A.; Poole, C. A comparative study using two methods to produce zeolites from fly ash. Miner. Eng. 2004, 17, 167-173. [CrossRef]

13. Kunecki, P.; Panek, R.; Wdowin, M.; Franus, W. Synthesis of faujasite (FAU) and tschernichite (LTA) type zeolites as a potential direction of the development of lime Class C fly ash. Int. J. Miner. Process. 2017, 166, 69-78. [CrossRef]

14. Wdowin, M.; Franus, M.; Panek, R.; Badura, L.; Franus, W. The conversion technology of fly ash into zeolites. Clean Technol. Environ. Policy 2014, 16, 1217-1223. [CrossRef]

15. Querola, X.; UmanÄaa, J.C.; Planaa, F.; Alastueya, A.; Lopez-Solera, A.; Medinacelib, A.; Valerob, A.; Domingob, M.J.; Garcia-Rojo, E. Synthesis of zeolites from fly ash at pilot plant scale. Examples of potential applications. Fuel 2001, 80, 857-865. [CrossRef]

16. Wang, S.; Zhu, Z.H. Characterisation and environmental application of an Australian natural zeolite for basic dye removal from aqueous solution. J. Hazard. Mater. 2006, 136, 946-952. [CrossRef] [PubMed] 
17. Katsou, E.; Malamis, S.; Tzanoudaki, M.; Haralambous, K.J.; Loizidou, M. Regeneration of natural zeolite polluted by lead and zinc in wastewater treatment systems. J. Hazard. Mater. 2011, 189, 773-786. [CrossRef] [PubMed]

18. Vyšvařil, M.; Bayer, P. Immobilization of Heavy Metals in Natural Zeolite-blended Cement Pastes. Procedia Eng. 2016, 151, 162-169. [CrossRef]

19. Shanableh, A.; Kharabsheh, A. Stabilization of $\mathrm{Cd}, \mathrm{Ni}$ and $\mathrm{Pb}$ in soil using natural zeolite. J. Hazard. Mater. 1996, 45, 207-217. [CrossRef]

20. Kronbauer, M.A.; Izquierdo, M.; Dai, S.; Waanders, F.B.; Wagner, N.J.; Mastalerz, M.; Hower, J.C.; Oliveira, M.L.; Taffarel, S.R.; Bizani, D.; et al. Geochemistry of ultra-fine and nano-compounds in coal gasification ashes: a synoptic view. Sci. Total Environ. 2013, 456-457, 95-103. [CrossRef] [PubMed]

21. Minchener, A.J. Coal gasification for advanced power generation. Fuel 2005, 84, 2222-2235. [CrossRef]

22. Wang, B.; Zhou, Y.; Li, L.; Xu, H.; Sun, Y.; Wang, Y. Novel synthesis of cyano-functionalized mesoporous silica nanospheres (MSN) from coal fly ash for removal of toxic metals from wastewater. J. Hazard. Mater. 2018, 345, 76-86. [CrossRef] [PubMed]

23. He, K.; Chen, Y.; Tang, Z.; Hu, Y. Removal of heavy metal ions from aqueous solution by zeolite synthesized from fly ash. Environ. Sci. Pollut. Res. Int. 2016, 23, 2778-2788. [CrossRef] [PubMed]

24. Bai, J.; Li, W.; Li, B. Characterization of low-temperature coal ash behaviors at high temperatures under reducing atmosphere. Fuel 2008, 87, 583-591. [CrossRef]

25. Huffman, G.P.; Huggins, F.E.; Dunmyre, G.R. Investigation of the high-temperature behaviour of coal ash in reducing and oxidizing atmospheres. Fuel 1981, 60, 585-597. [CrossRef]

26. Ojha, K.; Pradhan, N.C.; Samanta, A.N. Zeolite from fly ash synthesis and characterization. Bull. Mater. Sci. 2004, 27, 555-564. [CrossRef]

27. Rujiwatra, A.; Phueadpho, M.; Grudpan, K. Selective synthesis of zeolitic phillipsite and hibschite hydrogarnet from lignite ash employing calcium hydroxide under mild conditions. J. Phys. Chem. Solids 2005, 66, 1085-1090. [CrossRef]

28. Shigemoto, N.; Hayashi, H. Selective formation of Na-X zeolite from coal fly ash by fusion with sodium hydroxide prior to hydrothermal reaction. J. Mater. Sci. 1993, 28, 4781-4786. [CrossRef]

29. Murayama, N.; Yamamoto, H.; Shibata, J. Mechanism of zeolite synthesis from coal fly ash by alkali hydrothermal reaction. Int. J. Miner. Process. 2002, 64, 1-17. [CrossRef]

30. Rayalu, S.; Meshram, S.U.; Hasan, M.Z. Highly crystalline faujasitic zeolites from fly ash. J. Hazard. Mater. 2000, 77, 123-131. [CrossRef]

31. Kalyani, S.; Srinivasa Rao, P.; Krishnaiah, A. Removal of nickel (II) from aqueous solutions using marine macroalgae as the sorbing biomass. Chemosphere 2004, 57, 1225-1229. [CrossRef] [PubMed]

32. Onundi, Y.B.; Mamun, A.A.; Khatib, M.F.A.; Ahmed, Y.M. Adsorption of copper, nickel and lead ions from synthetic semiconductor industrial wastewater by palm shell activated carbon. Int. J. Environ. Sci. Technol. 2010, 7, 751-758. [CrossRef]

33. Panneerselvam, P.; Bala, V.S.S.; Thinakaran, N.; Baskaralingam, P.; Palanichamy, M.; Sivanesan, S. Removal of nickel(II) from aqueous solutions by adsorption with modified ZSM-5 zeolites. J. Chem. 2009, 6, 729-736. [CrossRef]

34. Kocaoba, S.; Orhan, Y.; Akyüz, T. Kinetics and equilibrium studies of heavy metal ions removalby use of natural zeolite. Desalination 2007, 214, 1-10. [CrossRef]

35. Abdel Salam, O.E.; Reiad, N.A.; ElShafei, M.M. A study of the removal characteristics of heavy metals from wastewater by low-cost adsorbents. J. Adv. Res. 2011, 2, 297-303. [CrossRef]

36. Hui, K.S.; Chao, C.Y.; Kot, S.C. Removal of mixed heavy metal ions in wastewater by zeolite 4 A and residual products from recycled coal fly ash. J. Hazard. Mater. 2005, 127, 89-101. [CrossRef] [PubMed]

(C) 2018 by the authors. Licensee MDPI, Basel, Switzerland. This article is an open access article distributed under the terms and conditions of the Creative Commons Attribution (CC BY) license (http://creativecommons.org/licenses/by/4.0/). 